\section{artelogie}

\section{Artelogie}

Recherche sur les arts, le patrimoine et la littérature de l'Amérique latine

15 | 2020

Latin American networks: Synchronicities, Contacts and Divergences.

\title{
Traducir la impenetrable. Una conversación con Julieta Hanono
}

Andrea Giunta

\section{OpenEdition}

Journals

Edición electrónica

URL: http://journals.openedition.org/artelogie/4512

DOI: 10.4000/artelogie.4512

ISSN: 2115-6395

Editor

Association ESCAL

Referencia electrónica

Andrea Giunta, «Traducir la impenetrable. Una conversación con Julieta Hanono », Artelogie [En línea], 15 | 2020, Publicado el 06 mayo 2020, consultado el 07 agosto 2020. URL : http://

journals.openedition.org/artelogie/4512 ; DOI : https://doi.org/10.4000/artelogie.4512

Este documento fue generado automáticamente el 7 agosto 2020

Association ESCAL 


\title{
Traducir la impenetrable. Una conversación con Julieta Hanono
}

\author{
Andrea Giunta
}

\section{Introduction}

2 Esta entrevista con la artista Julieta Hanono se realizó durante de 2019 en ocasión de su exposición Traducir la impenetrable, en el Museo de la Cárcova, en Buenos Aires. Julieta nació en Rosario, Argentina, y vive París. Durante su adolescencia estuvo detenida-desaparecida por la dictadura militar argentina. Estudió arte y filosofía en Argentina y luego en Francia. Su film $E l$ pozo remite a su experiencia en prisión. Durante los últimos años su trabajo se ha centrado en el tema de la traducción.

3 El Museo de la Cárcova reúne una colección de calcos antiguos y clásicos que Hanono intervino con sus instalaciones. Por un lado, trazó sobre el piso del museo, trepando entre esculturas y pedestales, una red con los nombres de poetas latinoamericanas que se conectan con líneas de colores violeta (color del feminismo histórico), verde (que representa la campaña por la legalización del aborto), naranja (que remite a la separación entre la Iglesia y el Estado). Nombres y líneas tejen una Cosmología de las poetas (2018-2020), una red que atraviesa todo el espacio del museo. En otra sala se presenta el video La riqueza de las naciones (2016, colección MALBA), un video de doble canal. Uno proyecta la caída del sol en las Cataratas del Iguazú, el otro un fragmento de La riqueza... de Adam Smith. La instalación propone una reflexión crítica sobre el pensamiento del economista y filósofo escocés y su análisis sobre la constitución de la riqueza.

4 Traducir la impenetrable incluye el trabajo que la artista realizó en colaboración con integrantes de la comunidad de pueblos originarios qom, provenientes de El Impenetrable en Chaco, que viven en Rouillón, en las afueras de la ciudad de Rosario, Argentina. Sus interlocutores en esta comunidad son Arsenio, quien realiza las figuras de animalitos de barro y Ruperta, quien trasladó especies vegetales desde chaco a Rosario. La multitud de pequeños animales remiten a la idea de diáspora (Animalitos / La manada, 2018). Son tantas vidas como los 
kilómetros que separan Buenos Aires de Resistencia: 935. La exposición incluye el herbario que Julieta realiza a partir de la impresión directa de las especies vegetales que Ruperta le regaló de su jardín. Las impresiones en papel vegetal translúcido se superponen creando una textura visual delicada (El jardín mágico de Ruperta, 2019). En otra sala cuelga una serie de impresiones realizadas en blanco sobre blanco (Una capucha de nubes, 2013-presente) de un texto en el que Julieta condensa su experiencia de estar entre dos lenguas, el español y el francés. Ella agrega una versión en qom que traduce Arsenio. Sintetiza así la experiencia diaspórica de la comunidad qom y la que ella misma condensa en su vida entre Paris, Buenos Aires y Rosario.

\section{Andrea Giunta}

6 Te formaste en el grabado, hiciste una obra con bordados (casi suturas amorosas), comenzaste luego con la fotografía y el video y en los últimos años ampliaste tus lenguajes a los de la poesía y la traducción. ¿Podrías contarnos por qué se producen estas elecciones, tal fluidez y coexistencia de los lenguajes? ¿Encontraste un lenguaje definitivo o lo que te define es justamente esa migración constante entre la palabra, sus dobles (las traducciones) y las mil técnicas para capturar imágenes?

Julieta Hanono

8 tal vez estas migraciones pueden llamarse también cambios de piel, como hacen las serpientes, especialmente las anacondas del río Paraná, que tanto me gustan, que cambian de piel, y siguen siendo las mismas pero diferentes, pues como ellas, yo cambio de lugar y de lengua

9 irme de Argentina significó irme de una lengua tan próxima al cuerpo (la lengua materna, de mi madre) que me dejaba pegada en el afecto y no podía decir, pues todo era tan compacto, no podía encontrarme en el espacio de la justa soledad de mi ser, para crear mis propias armas, que podemos llamar un lenguaje, un nuevo abecedario

el encuentro con otra lengua lo vivo como una revolución, una vuelta de 360 grados en el eje de mi misma, tuve que de-construirme (en términos derridianos), si empujo más todavía doy la imagen de una cosmonauta que entra en un agujero negro y sale del otro lado, siendo la misma y distinta

11 para mí las técnicas están íntimamente ligadas a lo que uno necesita decir, al servicio de una necesidad íntima, la técnica del grabado y en especial la punta seca, lleva en sí el gesto de la inscripción, es analógica a la escritura, es un modo de escribir donde el acento está puesto en la fuerza que ejerce la mano sobre la materia, sobre la placa de aluminio o de cobre, cuando de niña comencé a escribir, recuerdo que hacia palotes y ... al comienzo la escritura hace mal, es como aprender a tocar la guitarra, los dedos agarrando fuerte el lápiz contra el papel.., la sensación con la punta seca es similar, y no es anodino que fuese la primera técnica que utilicé

12 la fotografía, fue una necesidad para entrar en mí, no podía hacerlo de otra manera, necesitaba una imagen que me acercara a lo más real, salirme de la metáfora, de la narración, del gesto de mi propia mano, que ya había realizado desde el dibujo o la pintura,

13 la fotografía capta, y de manera inmediata (pues la cámara que utilicé era una cámara digital que capta la imagen y la reproduce en la pantalla al instante), posteriormente las imágenes eran trabajadas para alejarlas para aun más y enfriarlas, 
realicé fotos con el espéculo introducido en mi propio sexo, quería hablar del interior de mi cuerpo que albergaba a mi futuro hijo, y ese espéculo era una lupa y a la misma vez una cerradura para ver y espiar, así me apropiaba de un lugar misterioso, y al mismo tiempo hablaba de la caverna de mi madre y tal vez desde un lugar, de la lengua materna,

pude volver, entrar, armada detrás de una cámara de video (como el espejo de Perseo) al pozo de Rosario, el centro de detención clandestina donde estuve detenida desde 1977 a 1979, la técnica del video podía captar mi cuerpo allí, diría, podía hacer un registro del presente, de mi inquietud, mi miedo, mi sorpresa al volver,

baje aparejada, protegida por la cámara que es como un otro ojo, (no es anodino filmar en un lugar donde el tiempo queda fijo, es poner en movimiento lo que a estado detenido, quieto) la experiencia de tocar lo real fue fundamental para todo mi trabajo,

como era tan difícil, casi imposible decirlo en imágenes, pues no había imágenes para decir lo indecible, decidí nombrar toda esa desaparición con nuevas palabras, las palabras desde esa otra lengua, la lengua francesa, que me había dado la posibilidad de tomar distancia,

comencé a escribir, no desde la traducción, sino desde el balbuceo, como quien aprende a hablar, y en ese ejercicio que finalmente es oscilatorio (pues sueño en francés como en español) escribiendo en esta lengua nueva, volvía a la de antes, pero ya posicionándome desde otro lugar, y al mismo modo creando un entre-lengua significando mi no lugar

no puedo decir que mi lenguaje es definitivo pero sí diré que es definitiva esta oscilación entre un lugar y el otro, lo comprendí desde el ejercicio de la escritura, en esa dialéctica pude entender el camino de mi propia persona para ser persona, cómo necesité mudar de piel y de lengua para salirme de la presencia de un pasado siempre próximo, de un real como el de haber visto a los 16 años, lo inhumano de un centro clandestino, de haberlo tocado con mi propio ser, y de haber salido

Para muchos -y me incluyo- esa salida de la lengua materna puede ser traumática. Quizás porque viví fuera de los Estados Unidos siendo mayor que vos cuando te fuiste a Francia, supuso un desdoblamiento difícil, sin alegría. Esta es la experiencia de muchos emigrados. Sin embargo, para vos fue una circunstancia creativa, que sacó lo mejor de vos. ¿Quizás porque te alejaste de la lengua materna para ser la lengua madre de tus hijos? Como sea, creaste una cantidad de dispositivos visuales y sonoros (el ritmo de la palabra-poesía que se pronuncia) que te llevaron a lo que nombrás como una revolución. ¿Que condiciones propias crees que tuvo que la lengua nueva fuese el francés? ¿Cuál era tu familiaridad con el idioma? ¿Crees que otra lengua hubiese provocado en vos la misma experiencia?

21 me fui y pensé que no iba a extrañar, rompí mi billete de vuelta, como quien se va de una casa da un portazo y lanza esa llave lejos, tenés razón, la experiencia de salirse de una lengua es dolorosa, siempre deja un gran vacío, lo que me decís con respecto a tu propia experiencia me resuena, pienso que todos los inmigrantes hacemos un duelo de la lengua materna, y no solamente de la lengua sino un duelo del paisaje que podríamos nombrar de la infancia

llegar a París no era solo huir de algo, era ir a encontrarme con otra cultura con sus límites y sus posibilidades, pasar del otro lado del espejo, desde París me vi, no 
solamente argentina, me comprendí sudamericana, necesite irme al norte para saber que vibro desde el sur, en otro punto, con otra vibración energética cuando me fui creí (y lo digo con el énfasis que uno le puede otorgar a una creencia desde un punto de vista sobrenatural y salvadora) que los fantasmas del pasado se irían a disipar y sin embargo volvieron con mas fuerza, desmaterializados como ruinas que emergían en un paisaje nuevo y extraño, pero esta condición de aislamiento de saberse un pez de otra agua me hizo constatar que tampoco era pez del agua en mi lengua materna, irme fue entender que la singularidad de una mirada personal nos condena a ser siempre extranjera

París me otorgó esa evidencia que fue cruel y salvadora, puntapié inicial de mi creación, ese espacio que enciende que podemos nombrarlo poesía, lugar singular del ser, punto de soledad, que nos hace únicos y en un punto intraducibles

fue esa lengua que me posibilitó destruir mis mitos personales, mis tics de seducción, mis facilidades, construyendo mi piso a la medida de la marcha de mis pasos, pude entender que lo que nombro como arte es consecuencia del despliegue de mis ideas iniciales, de mis primeras emociones de niña, desde lo mas íntimo, ya descolocado de las gramáticas habladas por el otro, pues otra lengua ayuda a salirse de lo que denomina Lacan el parlêtre (el ser hablado por los demás) y uno, balbuceando, aprende a escucharse

si en la prisión estaba sola, no estaba en soledad, pues nunca se está solo con sus perseguidores acechando, París me obligo a ver, mis ojos tocaron las cosas, y pude tocar lo que siempre había visto en figuritas, ver la pincelada de Philippe de Champaigne, los pliegos del mantel de la última cena, sus rojos grises de la capa que cae del cardenal Richelieu, me sumergí en los nenúfares de Monet y vi una ciudad circular fruto de la reflexión que al mismo tiempo me asfixiaba, severa, pero me obligaba esta vez a salirme, volando, subiendo un espiral ascendente

cuando llegué un amigo gay me llevó al hospital y me hice un análisis de sida, me sorprendí porque era gratuito y anónimo, mas tarde, cuando estaba casada y ya madre de mi primer hijo, aborté, lo hice también en un hospital del estado, no existe el paraíso, pero es verdad que ciertas cuestiones que tocan a lo femenino yo las encontré resueltas,

en Buenos Aires había leído El tercer sexo de Simone de Beauvoir, si bien las posiciones patriarcales están en todas las sociedades y se ejercen detrás de diferentes mascaras, este nuevo contexto me otorgo cierta confianza y me ayudo a desanudar miedos concretos ligados a momentos dramáticos de mi vida, en mi país de origen

París, la lengua francesa me dio alas, esas alas para poder sobrevolarme a mi misma para entender que mi militancia de joven mujer está siempre y que hoy se encarna desde otros lenguajes, pudiendo inventar soluciones visuales, poéticas, y agregaré sonoras, pensado en lo que me preguntás, pues mi escritura es un doble juego de palabras y sones,

31 hoy mis proyectos artísticos, los hago encontrándome con otras personas, que pertenecen a disciplinas diversas, que me enseñan sus otras lenguas, creando proyectos que me exceden y finalmente son producciones económicas políticas sentimentales inscribir una nueva lengua en la lengua de mis hijos, ellos están atravesados por las dos, yo les cantaba entre mis dos lenguas, el francés que hablo es el de una extranjera, ellos 
están acunados por mi acento, son mestizos, ser madre es salirse de la lengua del cuerpo de su madre, para crear la propia

Volvamos a El Pozo, ¿por qué decidiste regresar al lugar en el que te habían tenido presa? Cuando entraste con la cámara, ¿era la primera vez que lo visitabas?

no fue una decisión muy pensada, fue más del orden de lo intuitivo, bajo al Pozo como una arqueóloga que quiere encontrar objetos contundentes que prueben su idea acerca de los vestigios del pasado, este pasado estaba muy vivo en mi misma, resonaba como ya lo dije de manera fantasmagórica, me perseguía en París, me impedía volver a Argentina, un abismo de ausencias,

35 necesité entrar en mi cuerpo a través de las fotografías de mi sexo y el espéculo que lo espiaba, para más tarde poder entrar en mi prisión, tal vez pude hacerlo porque me salí de la lengua que me contenía y encerraba, en el lugar imaginario del útero de mi madre, salirme de su cobijo, liberarme, cuando desde mi propio cuerpo infantando dejé de ser solamente hija

tomar esta decisión, que como ya lo dije, no era premeditada, fue dar un salto a la inversa, entrar a la caverna de el Pozo como quien entra a la gruta de su madre, fue casi, como volver de la nada, de la misma nada de donde venimos

fue un viaje iniciático, tocar el Pozo fue tocar lo real, lo que es del orden de lo impensable, desde antes de las palabras pues es indecible, la violencia total de lo que llamaría Giorgio Agamben un estado de excepción, ví lo que no pensé nunca ver y tenía que hacer de eso algo, pues se agolpaba en mí y me impedía vivir, yo quería decírmelo a mi misma, tal vez así, para poder decírselo a los demás,

hubo cuestiones objetivas, un cambio de gobierno, una apertura en las cuestiones de los derechos humanos, cuando hice una instalación allí, lo abrimos a los vecinos y fue junto a las asociaciones de madres e hijos

la primera vez que bajé, ya lo hice con la cámara, recuerdo que la noche anterior estuve muy enferma, era tan poderoso volver y saberme del otro lado, comprobar con mi propio cuerpo esa catástrofe irreparable, y el lugar me pareció mas pequeño

\section{¿Podrías describir cómo es y cómo se organiza la secuencia fílmica de El Pozo?}

en realidad, filmé mucho, recorrí todo el espacio detrás del ojo de la cámara, elegí ciertas secuencias que me parecieron que, más que ilustrar el lugar, lo sacaban de la narración y hacían aparecer la estructura misma

en el film El Pozo, construyo otra narrativa que deconstruye, hago de este espacio un no lugar flotante que es también una pecera,

la cámara esta ubicada en el hall circular del segundo piso, era el lugar de los interrogatorios, la cámara gira, y se ven todas las puertas abiertas, restos de cosas en el suelo, que pueden sugerir colchones tirados, ventanas tapadas, un pequeño escritorio (el del interrogador),

la cámara gira, la secuencia esta tratada a muy baja velocidad, la cámara allí también puede leerse como el ojo del panóptico, para mí significaba otra cosa, yo la puse en ese lugar y filmo desde un punto de vista que nunca hubiera podido tener desde mi condición de prisionera, pues nosotros estábamos adentro de los cuartos, no podíamos tener acceso al hall, esta ubicación corresponde a la de una persona libre, que ya se encuentra afuera o sino, a la del torturador, pero nunca desde la mirada del prisionero 

encandila mujer de ahora Colina Negra,

filmé de día, con luz natural, la secuencia de El Pozo, como una torre girando sobre si misma, en un tiempo detenido en su continua rotación, luego ensamblo con una secuencia que capturo de la instalación que realicé en el ex centro clandestino, era un proyector donde proyectaba una imagen de mi cara, finalmente decidí sacarla y dejar el halo de luz, la luz del interrogatorio, la luz brutal del proyector que nos interpela y

Todas tus obras mantienen un diálogo intenso con la escritura, con otros textos. Convertís a la escritura en imagen. Elaborás la transición entre la palabra y la imagen. Y escribís. ¿Siempre escribiste o hubo un momento en el que comenzaste?

desde muy pequeña escribo, solo para mí, mamá me dio un diario íntimo, en cuero rojo y con un candadito, era mi tesoro, amigo y confidente, yo tenia 7 años, a veces, lo vuelvo a abrir, y encuentro vestigios de ésta que soy, los cimientos que hacen a esta

la escritura, si la entendemos como la construcción de un lenguaje, en el que me inscribo en un estilo personal, comenzó en París, en el 2009

fue totalmente sorprendente, pues empecé a escribir sin pensarlo, desde el francés, un texto que relata el viaje del encuentro con las bordadoras de Tehuacán, México, en la

las convoco para bordar a partir de un modelo, 395 veces, el resto del vestido que yo había bordado, inspirada en los motivos de sus bordados

te referís a esta pieza, y hablas de suturas amorosas, voy a retomar tu bella definición, si, era un gesto reparador, pedir que mujeres me acompañaran en esos días de desasosiego, que me rodearan, abrazándome, con sus manos bordando, pues los 395 bordados que las mujeres realizaron significan los 395 días pasados en cautiverio,

52 también fue mamá, que, esta vez me dio una tela blanca e hilos de color, para hacerme un vestido para tener esperanza, y pensar que podía existir un día, en el que pudiera salir, vestida con mi vestido,

mi texto son fragmentos unidos entre las dos lenguas, donde se mezcla la experiencia de la producción de 395 y el otro viaje, al corazón del pasado en mi lengua materna, los mismos se superponen, se contaminan, alterando un tiempo con el otro, el antes es el después, todo coexiste en el ahora, mientras que una lengua, la francesa dice, la otra, la argentina, dice de otra manera

escribí 4 paginas y seguí a 40, tuve el privilegio enorme de que mi primer lector, ya no desde el círculo más íntimo, fuera el poeta y pensador martinicano, Édouard Glissant, el padre del concepto de creolización

55 le mostré mi manuscrito, con tanta inquietud, él vivía en un gran apartamento a Invalides, ya el tiempo le había pasado, estaba cansado pero erguido, este gigante hermoso, negro y macizo, y con la sonrisa de un niño travieso,

6 me pidió que numerara las páginas, y las iba leyendo y riendo de mis faltas de ortografía, faltas que yo misma no veía, ni aun veo, me dijo, así esta muy bien corrigió algunas, dejó otras, y así comencé a escribir

57 las palabras, mejor dicho, las ideas, me resultaban mas claras desde la otra lengua, yo podía olvidar para recordar y así ubicarme como quien se mira a si misma, ser la relatora de una historia de tiempos mezclados, 

los modernos, los occidentales, no es la verdadera vida, para ellos la realidad es cuando están bajo el efecto de drogas alucinógenas, potentes sustancias que extraen de plantas y de raíces

64 si avanzamos en que toda relación hacia el otro implica una traducción, pues el discurso que enuncio resuena distinto al del receptor, cada sujeto conlleva su lengua propia, la marca matriz de una historia gestada antes de nacer y tal vez, para ser receptivo, necesitamos siempre traicionar nuestra primera escritura

y la poesía, no es una traición a la lengua, algo que aparece como una fulguración que se construye desde lo inventado?

Es muy interesante tu relato sobre esa situación intersticial respecto del idioma. Dicen que traducir es también traicionar. $Y$ esto de hecho sucede en tus obras, en las que las palabras pueden estar más allá de la escritura correcta, mezclando y alterando las lenguas $i$ Funciona esta metáfora intersticial en tu proceso de estarentre?

la lengua? al sujeto de la lengua? a cierto, attachement (la palabra me sale en francés) en español se traduciría por ser atado, a veces me pasa que entre-pienso en una y la otra y tal vez, traiciono la otra, la olvido

precisa, a la manera de concebir mi lengua como me la enseñaron, a esa lengua aprendida en los años de escuela

remolino de los sueños, tal vez para mí la relación que tengo con la traducción, concibe una suerte de traición al lazo de sangre, al lazo con la lengua matriz

....y oscilando entre una $y$ otra, entre dos lenguas, entre afuera y adentro, me desato, me desanudo..

\section{¿Cómo es el juego entre las lenguas?}

tal vez este entre lenguas sea como columpiarse en una hamaca, un balancearse entre dos y abrir el juego, empujándose con la punta de los pies, tomando envión, estar en el aire, sobrevolando, como quien visita un lugar siempre nuevo, pues en ese va y viene, algo del orden de lo inusitado se produce

una mirada más alejada que permita poder nombrar las cosas con palabras, desde un modo singular y así hacerlas aparecer al mundo, será como ser una bisagra que sostiene esa puerta que se abre que se cierra que va desde un lado al otro,

la bisagra es algo que sirve para mantener las puertas para abrir y para cerrar, yo veo mi gesto inscripto en el aire, mi brazo extendido ilustrando la palabra, con mi mano torcida yo me alejo, no, esto no es un mango ni es mi muñeca, es un destornillador

entre dos lenguas, es un juego entre dos hemisferios, reconocerme sudamericana, una equilibrista entre norte y sur, sin renunciar a mi acento de extranjera, siendo una pasajera en viaje (como diría Charly) y guardar ese tesoro de sorpresa que es la capacidad de aprender, ser Alicia, siempre pasando del otro lado del espejo

¿Cuál es la lengua original y cuál la adoptada? 

códigos,

la original es la lengua que me hablaba antes de mi propia voz, la que me acunaba en el útero de mi madre, la matriz, la que aprendí a escribir primero con palotes

la adoptada es la lengua que me recibe y que encontré, es la lengua que tuve que aprender sacándome los hábitos (los tics) que conllevaba la otra, la aprendí por mi misma, a los tantoneos, como quien juega al gallito ciego, creando las mismas armas para acequiarla, haciendo mis papeles para ser ciudadana de otro lugar, adentrándome en una administración diferente con otras leyes, dándome la cabeza contra otros

me agarré a la nueva lengua, como quien se agarra a una tabla de salvación, me encontré con la lengua francesa, y esta significó una apertura de campo, como quien cambia el lente de su cámara y utiliza otro objetivo, pude tomar la distancia suficiente y pude recuperar la otra, para volver a decir mi lengua primera, desde mi propia originalidad subjetiva

\section{¿Soñás en las dos lenguas, pero todavía reconoces la diferencia entre las mismas?}

sueño en las dos, es cuando despierto, cuando vuelvo a la superficie, una frase o una palabra que emerge

ahora te escribo en español, estoy pensado en mi lengua primera, y ya contaminada por al otra, escribiendo en español me encuentro muy cómoda, si lo haría hiciese en francés sería tal vez un poco más complicado, pero cuando vuelvo a leerme constato mi manera de escribir, ya atravesada por la otra lengua,

escribo diferente porque pienso diferente, la travesía entre dos lenguas me otorga un espacio de aislamiento y tal vez avanzaría de levedad, desplegarme en la doble escritura es vivir la resonancia, pues otra lengua no es ni un eco ni una sombra, estoy hablando en una (pero me escucha la otra) es un lugar de compañía en ese entre-dos,

Homi Bhabha se refiere a la figura del mimetismo como una relación entre la lengua del conquistador y la del conquistado, el subalterno. Se trata de una estrategia, en un sentido, de supervivencia frente al poder. ¿Encontrás algún eco de esta relación en tu propia experiencia en Francia, país que llevó adelante una guerra cruenta contra una de sus colonias, Argelia, para citar tan solo un caso? ¿Cómo te ubicás afectiva y estéticamente en ese entramado de relaciones?

hablar de mimetismo a la lengua francesa seria obedecer al pie de letra sus leyes, y yo me salgo, el gesto de dejar ciertas faltas de ortografía y errores semánticos es no solo poético, sino político

en todo el despliegue de mi trabajo, desde mis textos que se presentan cual fragmentos testimonios, restos de imágenes de sueños, de carácter autorreferencial, hablados en primera persona, hasta la traducción a diferentes técnicas, diferentes lenguas,

2 tomo como primera referencia el trabajo con las bordadoras mexicanas, cuando a partir de ese modelo, ellas mismas traducen, a un modo personal, cada una, un objeto bordando a su manera

pienso en el texto Ils, traducido por el maestro Arsenio, a su lengua materna, el qom, él dice que se feminiza, se transforma en mujer para poder ser hablado y ponerse en el lugar de lo que habla,

4 insisto en que la traducción no es lineal, cada texto es equivalente, uno no traduce al otro, no hay una subordinación de mi escritura en argentino a la escritura en francés, 

nuevas, obras terminadas, obras que están en proceso. Estas obras funcionarán como intervenciones entre la majestuosa colección de calcos, que reproducen obras emblemáticas de la historia del arte occidental y también prehispánico. Estuvimos en el lugar e imaginamos cómo se dispondrían tus propuestas. Anticipamos los diálogos y las fricciones que se originarían y, sobre esto, quizás podamos pensar una vez que la exposición esté montada, como una coda a este texto. Quisiera por el momento conversar un poco sobre las obras específicamente. En principio, la exposición se titulará Traducir la impenetrable. Nos hemos detenido extensamente en la importancia que para vos tiene el lenguaje y la traducción, así como también los huecos, las perforaciones de la lengua que se producen en el ir y venir de una lengua a otra, síntomas que se manifiestan en desvíos gramaticales, en cierta incorrección respecto de los estándares de una lengua escrita, que el lector percibe como pequeños desórdenes cuyo sentido, sin embargo, comprende. En tu escritura es grato introducirse en su tono desajustado pero comprensible. Comencemos con el título, Traducir la impenetrable. Acabo de verificarlo en el diccionario y en verdad esa región de bosque nativo en el Chaco $(40.000 \mathrm{~km} 2)$ se llame "el" impenetrable. ¿Por qué en femenino? al comienzo de una frase, la palabra traducción esta conjugada, y deviene acción, será, traer, mostrar, decir a mi propia lengua, y como bien vos lo escribís, haciendo una suerte de juego, donde el error, funciona como un acto fallido que rompe el candado de la censura, construyendo una posibilidad utópica

pensé, entre otras cosas, en una obra de Jesús Rafael Soto, Penetrables (líneas verticales tendidas a cierta altitud que forman una superficie cúbica o rectangular, donde el público está invitado a entrar) la gente entra en esa selva de líneas, pero son líneas rectas, donde nadie puede enredarse 

enredadera manada. Rosario

la comunidad qom viene de otro lugar, un bosque tupido, una selva, donde es casi imposible entrar si no se es nacido allí, por eso se llama impenetrable,

la tierra qom es un útero, la pacha mama (a quien tanto Ruperta como Arsenio le rinden homenaje) feminizar, nombrándola desde un articulo femenino, es cargar este espacio de potencia, el artículo singular femenino -la- adelante, la convierte, vuelve a ser ese lugar, impenetrable, espacio de resguardo, de cobijo

-la- reactualiza, es una posición política y feminista, Traducir la impenetrable es volverla a sus propiedades primeras, desalambrarla, dejándola libre

traducir la impenetrable intraducible vitalidad salvaje, es traducir la selva, la femenina, la subversiva, las chamanas las brujas las serpientes que mudan de piel como de vestido, la lengua no escrita, nómade, que fluye escapa, trepa indomable como una

si lo femenino es misterio, lo misterioso no es penetrable, al misterio se nos inicia, para comprenderlo es necesario bajar las armas, llegar desnuda, despojándose de lo que uno antes conocía, y dejarse tomar por el laberinto mágico, no tenerle temor al canto de sirenas de las lenguas salvajes, ser hablada dejarse hablar por las aguas movedizas de las voces de las lenguas, mucho antes de nosotros

Ví fotografías extraordinariamente bellas de la instalación de pequeños animalitos que conforman como una constelación animal. Son como estrellas o como luciérnagas que crean una textura cálida sobre el blanco prístino en el que casi flotan o titilan. Contanos sobre el orígen de este trabajo colaborativo con los qom, sobre las distancias y sobre qué significa exponerlas juntas, como en

es tan bello lo que decís acerca de las figuritas de los animalitos cuando las nombras estrellas, y luciérnagas, los también llamados bichitos de luz se prenden y se apagan, llevan luz en ellas mismas, flotan, son pequeñas, y esa luz itinerante que emanan, podríamos decir, dice un abecedario como en un balbuceo

los bichitos me encontraron junto con los qom, cuando comencé a pensar la exposición para el Museo de la Memoria de Rosario, curada por María Elena Lucero, el hilo conductor de la muestra fue la traducción de uno de mis textos, Ils,

quien traduce es el maestro Arsenio Borges, gran artesano, el aprendió mirando a su abuelo que le enseñó a sentir bajo sus dedos la arcilla

traduciendo, se identifica con la mujer que cuenta la historia de su partida a otro país, Arsenio lloraba al hacer suyo el texto Ils, que relata el viaje desde Argentina a París y las dificultadas de encontrarse en otro lugar, otra lengua,

el traductor, se traduce a sí mismo y se encuentra con su propio éxodo desde Resistencia, Chaco en el impenetrable hasta el barrio Rouillon, en la periferia de

4 me cuenta los kilómetros que hace a pie, para llegar a instalarse en los bordes de la ciudad, empujado por la tierra que se secaba, la falta de comida, cuando me habla, comprendo que falta otra traducción, más cercana, que exceda la lengua escrita

traduzco a la artesanía, registro de la historia cotidiana escrita en letras minúsculas, la que se escribe en la vida corriente, tizándose entre los vestidos, los utensilios, la cocina, los juguetes, lengua de oralidad, como la lengua originaria qom, 
los 709 son los $709 \mathrm{~km}$ que Arsenio camina para llegar a Rosario, cada bichito $1 \mathrm{~km}$, modelados en arcilla cocida sin pintura,

el Centro el Obrador, en barrio Rouillon, donde vive parte de la comunidad, es el espacio que alberga este trabajo, su coordinadora, Mariela Mangiaterra, oficia de nexo entre mi proposición y el grupo, se discute en asamblea, el por qué los 709 animalitos, la gente emocionada, el precio lo determinan los artesanos, la inflación avanza, y en la paga final se tiene en cuenta, un vínculo de confianza se establece, la obra es todo el proceso de producción que la constituye

para la muestra Traducir la impenetrable, se producen 935 bichitos que corresponden a los Km entre Resistencia, Chaco y Buenos Aires,

relucen contra el blanco del plano, se expanden en la superficie, letras, o signos, abecedario de barro que agrupados son un discurso, portador de energía animada, luz propia, rítmica de luciérnagas, balbuceo de una nueva lengua que se inventa, porque la luz pequeña de cada una, en la suma, es una geografía abierta, el de la lengua antigua de la tierra libre que se desplaza

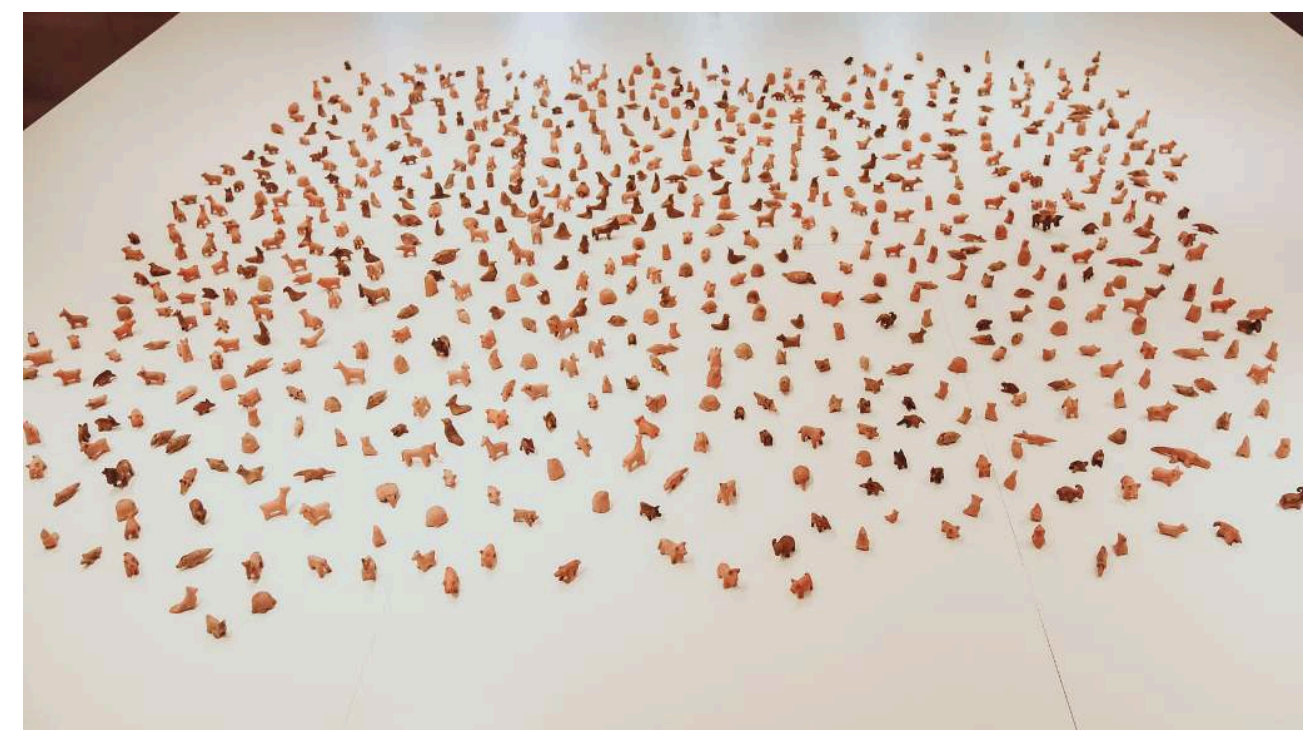

Julieta Hanono, Animalitos / La manada, 2018

110 Me deleita observar esos pequeños animalitos. Me proporcionan dos placeres para la mirada. Por un lado, la sensación de manada, todos juntos son como una grisalla. Por otro, el detenerse en cada uno, observar sus diferencias, tratar de adivinar o encontrar qué animal representan. Uno puede estar largo tiempo observándolos. Me parece interesante que su número sirva para medir la distancia. Y me pregunto, en estos momentos del debate sobre lo poshumano, sobre un feminismo que introduce las cuestiones relativas al antropoceno, la era en la que el hombre decide las transformaciones, incluso la destrucción del planeta, ¿qué sentidos adicionales tiene esa acumulación de vida animal? Pienso en la igualación o incluso en el desplazamiento de lo humano como parámetro de medida o como agente que establece las distancias a través de sus dispositivos métricos. Aquí se trata de una medida animal. ¿Pensaste sobre estas posibilidades interpretativas y sobre sus conexiones con un feminismo actual, que no solo implica denunciar la violencia hacia las mujeres, sino también la destrucción a la que parece irrevocablemente estar destinado el mundo en el momento actual del 
capitalismo global? Lo femenino como lo resistente al expolio de los recursos naturales del planeta (exacerbado por el autoritarismo de nuevos líderes como Trump o Bolsonaro), lo animal como parámetro afectivo que desjerarquiza la centralidad de lo humano. ¿Qué piensas sobre estas relaciones que pueden no ajustarse al lugar desde el que pensaste esa pequeña jungla de barro?

tus cuestiones abren, a medida que te respondo el hilo mismo de mi trabajo se va desplegando

el bosque, la selva de barro es una invocación, ningún animalito es fruto de la invención, cada pequeña figura carga con el peso del ansia de hacerla volver, Arsenio y su compañera Clorinda, artesana también, uno al lado del otro, van corrigiéndose las esculturas, ellos insisten en que los animalitos modelados, están en vías de extinción, cada uno conlleva la carga, es vestigio de lo que se está yendo, y del mismo modo sus preciosos animalitos ofician de testigos, testimoniando otro tiempo, el de sus primeras vidas en juventud, exodadas desde la abundancia de la selva a la precariedad de la villa miseria,

este territorio en movimiento, desde un punto de vista, representa y denuncia, lo que se está destruyendo, pero desde otro punto, puede ser interpretado como aparición de una memoria, supera la idea del vestigio, deviene una invocación,

114 los animalitos en grupo son un discurso desde otra mirada del mundo, no transformado por la mano invisible (Adams Smith) del capitalismo mercantilista y global, un discurso de horizontalidad donde todas las categorías de vitalidad van confundidas, desde lo vegetal lo animal lo humano, se mezclan y se nivelan

115 en la cosmología qom la noción entre animal y persona humana es desjerarquizada, el mito de la creación del pueblo qom esta trazado por esa doble pertenencia,

116 Cuando Kharta creó el mundo no existían el frío, la enfermedad, la muerte ni el hambre. Sólo creó hombres, como eran inmortales no tenían necesidad de tener hijos. Estos hombres eran mitad seres humanos y mitad animales. Tenían plumas y pieles en su cuerpo y garras en los pies $y$ las manos, algunos podían volar. Estos vivían felices cazando, pescando y recolectando, el mundo estaba creado para ellos y formaban una unidad entre hombres y naturaleza...

117 las únicas enteras, son las mujeres, mujeres estrellas (mira que lindo en relación, a lo que estamos hablando, cuando comparás los bichitos a estrellitas)

118 ...En esa época, de tiempo en tiempo, las estrellas bajaban del cielo por medio de cuerdas de chaguar para robar la comida de los hombres. Estas estrellas eran blancas, brillantes y tenían forma de mujeres. Elé las vio descender por las cuerdas y como eran muy lindas quiso tomar a una de ellas, pero estas mujeres tenían mucho poder y el hombre loro sufrió heridas en su boca, así perdió parte de su facultad de hablar. Mientras estaba dolorido en el suelo observó que las mujeres tragaban el alimento por arriba y por debajo, ya que también tenían dientes en la vagina...

aquello que encarna lo femenino es poderoso

...Chiquii llamó a una reunión, deliberaron largamente y decidieron que el hombre mosca volaría mas allá del mar para traer una solución. Cuando el hombre volvió trajo consigo el conocimiento del fuego, hasta ese momento los hombres comían el alimento crudo. Trajo también el viento, el frío, la enfermedad y la muerte.

121 lo femenino produce estupor, debe ser domado, los dientes de las vaginas rotos, el encuentro con el otro se asevera el fin de la eternidad y el comienzo de la vida humana, 

presente
...Los hombres se pusieron a cantar el día, llegó un fuerte viento mucho frío. Las mujeres que estaban desnudas se pusieron a temblar y se arrimaron al fuego. Los hombres entonces tiraron al fuego una piedra mágica que explotó y entrando en todas las mujeres les rompió los dientes de abajo. De esa manera los hombres animales se unieron con las mujeres estrellas y sus hijos son el actual pueblo Toba.

aquí lo femenino es entero, son casi-divinas, enfrentan a los hombre-animales, da a pensar esta diferencia, con la concepción judeocristiana occidental donde la mujer es creada a partir de una parte del hombre, en términos lacanianos, si el concepto de falo es una ilusión y que este se comparte, se podría decir que ellas, desde sus orígenes, comparten el mismo atributo y los hombres, para encontrarlas, deben perder su parte animal, que puede leerse como la renuncia a cierta manera de virilidad,

antes de la colonización, los qom se organizaban a través del concejo de ancianas y de ancianos, viviendo en equidad de géneros, después de la evangelización, los curas y pastores, representantes de la religión monoteísta, se erigen en dirigentes de la comunidad, conllevando un modelo masculino y paternalista, intentando demoler este sistema ancestral

Ruperta, representante qom, se define como guerrera, las guerreras legendarias eran las amazonas, palabra que viene del griego antiguo $\dot{\alpha} \mu \alpha \zeta \omega \dot{\omega} v$, sin pechos, la historia entre veraz e imaginaria cuenta que se cortaban el pecho derecho para sostener el arco,

Ruperta me dice que no le gustan los pastores (evangelistas) que les ponen una pollera larga a las mujeres y les impiden hablar

ya durante el descubrimiento de las Américas, Colon habla de una isla donde viven mujeres que podemos asemejarlas a ellas, el cura Gaspar de Carvajal cronista de la expedición del conquistador español Francisco de Orellana en el 1542, escribe como guerreras mujeres les disparaban desde el otro lado de la orilla, dardos de cerbatanas y flechas, consecuencia del impacto de su relato, el rio será rebautizado Amazonas o río de las Amazonas, aquí parte de su relato

...Han de saber que ellos son sujetos y tributarios de las Amazonas, y sabida nuestra venida, les van a pedir socorro y vinieron hasta diez o doce, que estas vimos nosotros, que andaban peleando delante de todos los indios como capitanas y peleaban ellas tan animosamente que los indios no osaban volver las espaldas...

Bolsonaro intenta olvidar que existen las amazonas, cuando expolia lo que considera suyo, el Amazonas, y me pregunto si en la mente de los hombres autoritaritos, sigue intacto el deseo de doblegarlas,

los animalitos en manada, territorio de pura vida sensible y gratuita, donde todo se confunde y se nivela, latiendo, diferente y al unísono, van construyendo un dique imaginario a las políticas invasoras que destruyen el planeta, luciérnagas, mujeres estrellas, amazonas, chamanas, discurso visual escrito en letras de barro, feminista, 


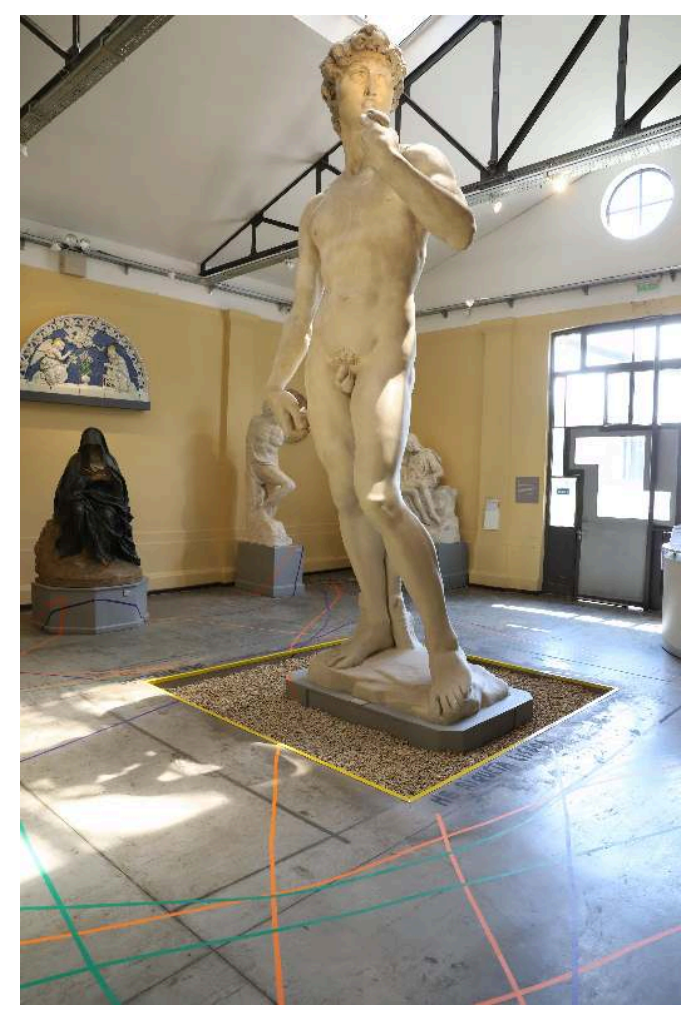

Julieta Hanono, Cosmología de las poetas, 2018 al presente

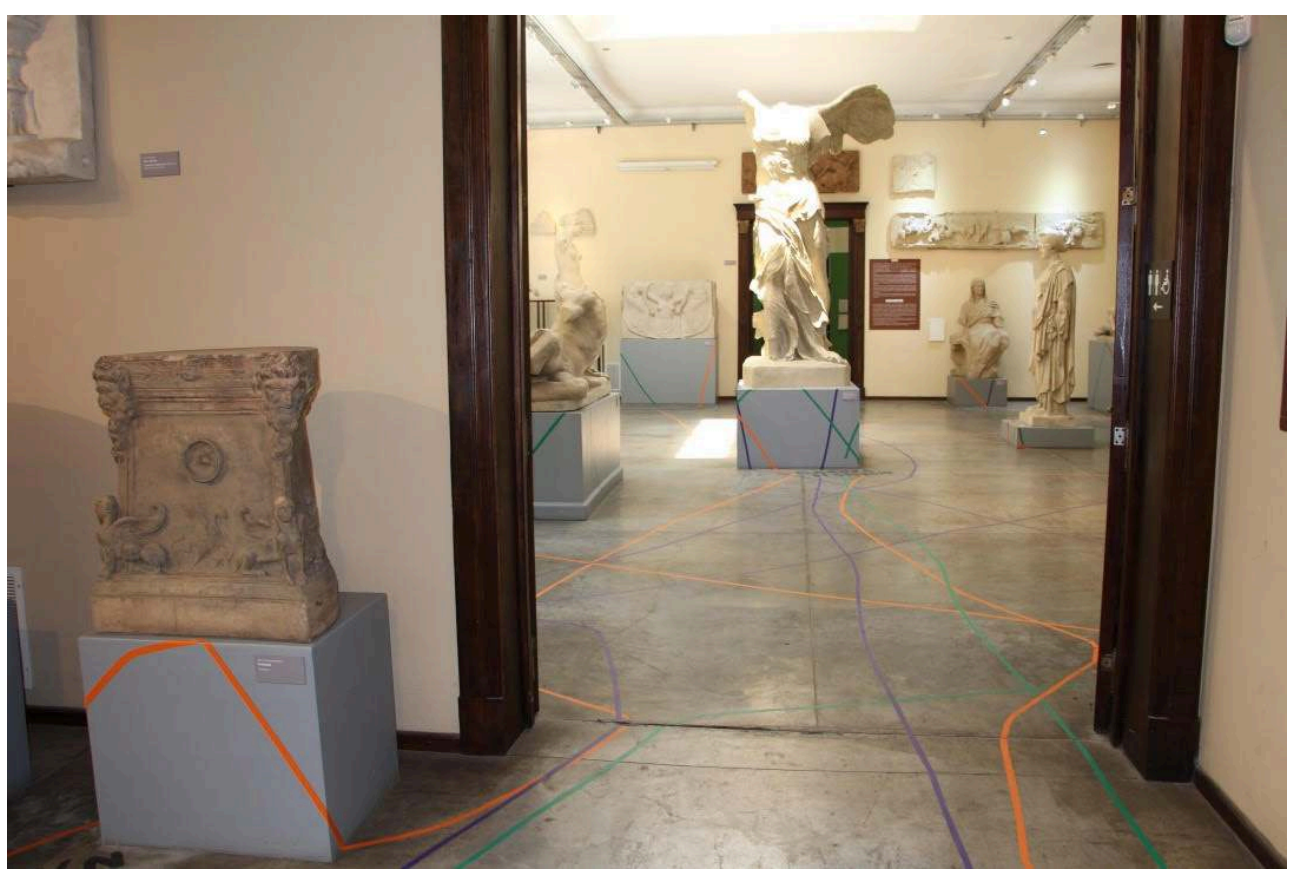

Julieta Hanono, Cosmología de las poetas, 2018 al presente

El feminismo aparece en la exposición como archivo desplegado en el piso, cuando trazas un mapa de las poetas, una cosmología la llamás, que produce la interacción de los nombres. Y todo esto vas a hacerlo en colores significativos para la lucha feminista que en los últimos años ocupó las calles: el violeta tradicionalmente vinculado con los feminismos; el verde, color que se vincula a la campaña para legalizar la interrupción voluntaria del embarazo; el naranja, que 
representa la separación de la Iglesia y el Estado, el freno a que la Iglesia continúe ejerciendo un poder sobre la sociedad civil para que el dogma que regula la vida de los creyentes se aplique a toda la sociedad. En la aplicación del dogma se deja de lado el hecho de que los abortos clandestinos, que suceden a pesar de la ley y de la Iglesia en todas las clases sociales, afectan especialmente a las mujeres pobres, ya que los aborto baratos se realizan sin condiciones seguras para sus vidas. ¿Por qué, entonces, anudar estos colores con la poesía? ¿es una relación pensada entre la política y la poética? ¿Por qué elegís a las mujeres que nombrás?

cuando atravesaban el mapa del mundo, las constelaciones guiaban a los antiguos para orientarse en la oscuridad de la noche, mis poetas, son una cosmología de conciencia que late e ilumina, tramado desde el suelo del Museo entre los calcos de esculturas (representantes de una mirada solo masculina) la cosmología de sus nombres entrelazados sube y desborda, interpelando años de historia, es la impenetrable trepando libremente, la subversión de la lengua resplandece

las nombro poetas, podría llamarlas luciérnagas, estrellas, sirenas, chamanas o hechiceras, con sus palabras invocando espíritus y fuerzas, irradiando luz de preguntas, abriendo el juego de la lengua, de-construyendo la manera en que la historia masculina ha concebido la escritura, rindiéndola intraducible, misteriosa, por eso anudar poesía y política es imprescindible,

citaré solo algunas, desplegando las intenciones de este mapa cosmológico, la más remota es Sor Juana Inés de la Cruz, expresión de la independencia al decidir su propia vida entrando al convento para hacer posible su deseo de ser una mujer que escribe, o Alfonsina Storni, que desde su poesía saca a la superficie el machismo de su época y transgrede las normas sociales en su existencia personal, Violeta Parra nómade, que va recopilando las coplas antiguas de su tierra, escuchando la voz mas frágil, la de los pobres, Susana Thénon en su doble pertenencia a la lengua, traduciendo al francés avanzando el feminismo, junto a Alejandra Pizarnik escribiendo su amor femenino a las mujeres entre Buenos Aires y París,

si las mas desamparadas, las mas pobres, sufren duramente la injusticia de un aborto clandestino, unir las poetas con los colores emblemáticos del feminismo, reactualiza lo vertiginoso de sus textos, le confiere un real, la poesía deja de estar en el limbo de lo poetizante, no es metáfora, es concreta, despoetizar la poesía es hacerla, como dice el poeta Gabriel Celaya, un arma cargada de futuro

en la invención de la poesía, subversión de la lengua, no solo lo escrito dice, es el cuerpo que habla, elijo estas poetas, un puñado de mujeres que escriben desde el cuerpo, construidas por esta relación entre escritura y vida, traductoras e interpretes de las vivencias de otras mujeres

los lazos en colores que las unen inventan un tejido haciendo aparecer esta relación secreta e invisible, la historia se rescribe, la personal, la de cada voz de la poesía de cada poeta, y la de todas, unidas en la sororidad de sus intenciones, y en un mundo hostil que no quiere escuchar, ellas abren otra historia de luchas que nos envuelve desde el suelo al cielo, la voz de la potencia femenina, en un coro de pensamiento escrito se levanta 


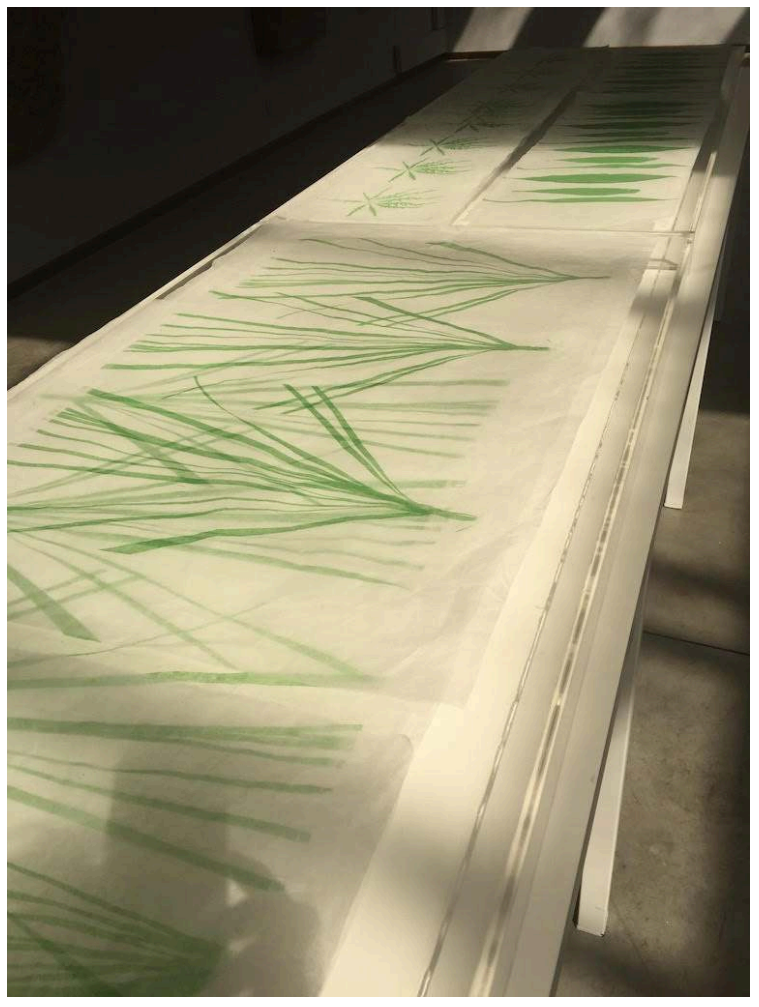

Julieta Hanono, El jardín mágico de Ruperta, 2019

El jardín mágico de Ruperta suena tan bello. Sé que te basas en el traslado de especies vegetales, plantas, flores, que Ruperta realizó desde el Impenetrable, donde vivía, hacia Rosario, donde fue trasladada. Existe una poesía conmovedora en esa travesía que vuelve dulce su extranjería, la situación diaspórica en la que se encuentra. Ese jardín es como una manta cálida en la que ella comprime el entorno de la selva en su jardín, casi un memorial de la naturaleza, un memorial afectivo que la acompaña y que cada día le recuerda de dónde viene. También aquí podemos pensar en lo poshumano. Vi las fotos que tomaste en el jardín de Ruperta e imagino cómo se verá ese herbario impreso en litografía en un papel translúcido. Conversamos sobre poner estas hojas en vitrinas iluminadas desde abajo en la sala en la que se encuentran los calcos prehispánicos. Separados como para poder caminar entre ellos. Contanos un poco sobre esta obra y qué representa en el conjunto que vas a disponer en las salas.

Ruperta dice vivo en Miraflores, lo dice desde su jardín, en el barrio Rouillon, en la periferia de Rosario, rodeada por sus plantas que trajo de su selva, ella es y está en los dos lugares y ese jardín significa su doble pertenencia,

Ruperta lleva con ella la mano verde, hace huertas en la comunidad, cuando me invita a su jardín me las enseña, hay también macetas colgadas en las ramas de su árbol donde vienen a cantar los pájaros y su amiga Roberta dice que llora a la mañana, cuando los escucha

ella escucha la selva y la selva es ella, y el herbario es una manera de decir que todo en la vida sensible se confunde, todo es animado y su árbol es mágico como todo lo que la rodea 
pero ella también es chamana, y el titulo jardín mágico no es anodino, es un canto de cada voz de los espíritus que animan cada planta y cada una es la memoria de la historia de su lengua, su gesto al traerlas, para rodearse de ellas, anula la distancia, y esa memoria se vuelve viviente

hubiera podido cortar las plantas, secarlas y producir un herbario en un sentido clásico, pero calcar es también otra manera de traducir, crear otro nivel de lenguaje, una técnica que me acerque a mis primeros trabajos, a la técnica del grabado

5 yo quería un papel que me encuentre con lo mas vegetal posible, fibra de la naturaleza, elegí finas planchas translúcidas de papeles japoneses, finos como las hojas de las plantas,

las cajas vitrinas que las albergan construyen una arquitectura del registro de lo vegetal, contenido en bloques luminosos, nos abren la retina a la delicadeza del detalle, en las nervaduras, mínimo, frágil, resistente, palpita la estructura misma de lo vegetal,

su jardín se compone de plantas para curar y proteger, como el Mapic que ahora es un árbol y sus chauchas poseen grandes propiedades nutrientes, o la Adelia que se coloca en las entradas de la casa para dar una buena bienvenida a los invitados

el jardín mágico es más que un pedazo de selva que va desde Miraflores a la periferia de Rosario, es un testigo tangible de su doble corazón, que tiene un pie en cada lado,

y ese jardín, es tele-portado al Museo desde otras maneras, es deconstruido desde la transformación de la materia planta en calco de papel, y reconstituido para elaborar el herbario en cajas,

palpitando de espíritus animados, el herbario pinta el autorretrato de Ruperta: sus plantas elegidas albergan los secretos de su magia

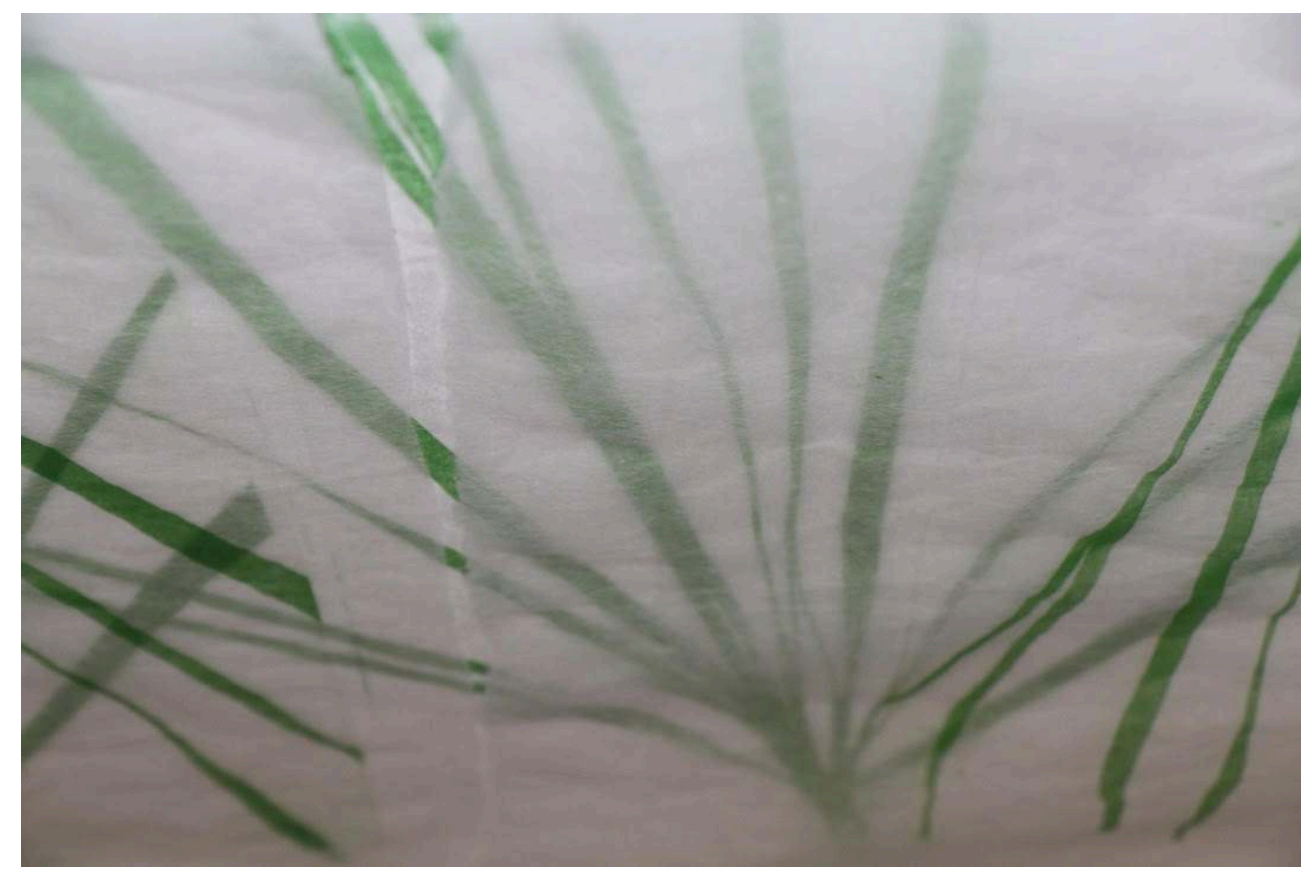

JULIETA HANONO, EL JARDÍN MÁgICO DE RUPERTA, 2018

Creo que también donde están los calcos prehispánicos vas a disponer la serie Una capucha de nubes, con afiches impresos en blanco sobre blanco. Viene a mi mente 
inevitablemente el eco de Malevich o de la argentina Lea Lublin, que, como vos, vivía en Paris, Ambos hicieron obras en "blanco sobre blanco". ¿Por qué esta impresión? ¿qué rol juega aquí la lengua? ¿qué palabras imprimís?

...cuando llegué a Paris, era la bruma, ellos quisieron mostrarme la ciudad, y me llevaron a Pigalle... cuando recién llegué, estaba envuelta entre los fantasmas del antes, como quien está ante un precipicio frente al mar y si se lanza podrá volar o caer, así me sentía cuando me topé con esas obras de Lea Lublin, imágenes blancas contra blanco, formas, sanadoras en ese momento de desasosiego,

estaba frente a ellas y me fascinaron, eran un espejo, me encontré con lo que me sucedía, mi ser que se reflejaba, empezar de 0 , ser una página que parece en blanco pero ya está escrita, en pintura invisible, Lea me pedía que mirara, que entrara con mis ojos para hacer aparecer ese discurso secreto

cuando el Macbal, Museo de Seine Marne, me propone hacer una estampa para el día de la mujer, pensé en una frase que englobara un idea de feminismo muy abarcadora, y encontré este fragmento de la introducción del capital tomo 1 de Karl Marx,

Perseo para perseguir los monstruos necesitó una capucha de nubes nosotros a esta capucha, la hemos bajado sobre nuestros ojos y nuestros oídos para hacer como si los monstruos no existen más

el texto es enigmático, lo podemos leer desde la pura reivindicación política pero también desde un punto de vista feminista, los monstruos siguen estando cuando se meten presas a las mujeres por abortar,

la misma articulación del discurso de la frase me llevó a pensarla en blanco, como devenir nosotros mismos invisibles para vencer a los monstruos, como yo podía devenir visible desde mi invisibilidad, para que el espectador se reapropiara de mi cuerpo?, un artista da a comer su cuerpo al otro, haciendo aparecer su discurso, pero también su corporalidad,

por eso, son afiches y del mismo modo anti-afiches, no muestran directamente, su intención no es la de comunicar (si pensamos lo que enuncia Foucault, con relación a la comunicación como instrumento de palabras de poder) el blanco sobre blanco, hace necesario un esfuerzo para hacer aparecer el discurso, este mismo no esta dado, es una pregunta, se establece una relación de deseo, el que quiere leerlo se implica en el mismo enunciado del texto que está leyendo

159 lo hice en francés, pero una capucha de nubes va traducido en todas las lenguas en las que se desplaza, manera de apropiárselo, desde cada lengua, en cada nuevo lugar, la técnica para realizar el afiche resulta diferente, significando que otra lengua es otra traducción, otra técnica,

160 ¡Boguen! El abismo libre, blanco, jel infinito frente de ustedes!

161 Kasimir Malevich, Del cubismo y el futurismo al suprematismo. El nuevo realismo pictórico, 1916.

el cuerpo, frente a lo que no se ve, la mirada al coincidir con la luz hace ver lo que no se veía, y así se puede descifrar el discurso secreto, y a la medida en que este va apareciendo, entendemos que la palabra es acción, verbo, que ese texto escrito, se va escribiendo en nuestro cuerpo 


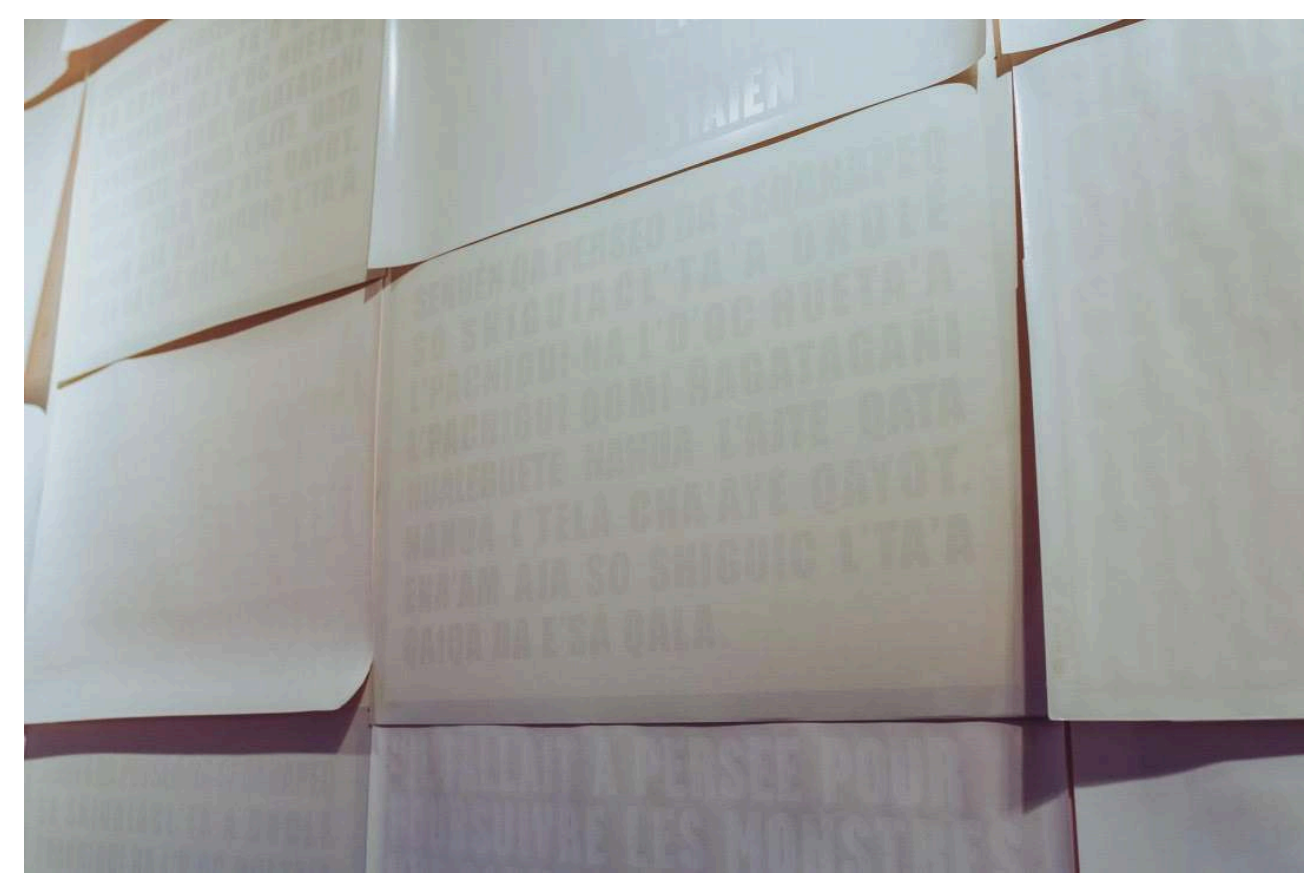

Julieta Hanono, Una capucha de nubes, 2013- al presente

Hablemos del film-texto La riqueza de las naciones, que también se incluye en la exposición en la Cárcova. Retomás aquí el texto de Adam Smith, del mismo título, de 1776. Entiendo que lo tomás como un punto de partida posible del orden económico global, de la mano del mercantilismo inglés y de la idea de un orden económico articulado por la noción de Commonwealth, de bien común, nueva retórica de un colonialismo comercial que trazaba mapas que se sobre imprimían sobre el orden colonial fundado en los sistemas administrativos y de control que regulaban, por ejemplo, el comercio entre las colonias y la corona española. 1776 es, si recuerdo bien, el año en el que se establecen las reformas borbónicas, con Carlos III, que establecen nuevos virreinatos y un sistema de comunicación un poco más abierto que aquél que regulaba el reconocimiento de solo dos puertos legales, Veracruz y el Callao. Todo indica que en este momento se estaban cambiando las reglas del juego que regía la noción de 'mundo'. Elegís para este film el capítulo "Las colonias" que transcurre como los créditos en el cine, de abajo hacia arriba. $Y$ acompañás el texto con el film de un atardecer en las cataratas del Iguazú. El sol es chupado por el horizonte de arriba hacia abajo. ¿por qué estableciste esta relación precisa entre imagen y texto? ¿Cuál es el sentido político que este tiempo demorado en el que transcurren imagen y texto quiere activar?

me estaba separando de mi marido, viajé con mi hijo menor, la habitación daba directo a las cascadas, un hotel colonial dentro del parque de las cataratas del Iguazú

bajé con la cámara, estaba frente a las cataratas, el parque cerrando, ya no quedaba casi nadie, los colectivos con los turistas partían, y me quedé sola frente al sol que caía, envuelta entre la luz y el sonido, era tan intenso que coloqué la cámara en el reborde bien frontal para captar lo que estaba sintiendo, y la dejé correr y me quedé al lado de ella mirando como el sol bajaba entre las nubes de vapor el agua y los arcoíris, el canto de los pájaros los ruidos de los animales los zumbidos de los insectos, el olor de las plantas toda esa vitalidad encendida 

colonizador

gravé adentro mío la sucesión de ese tiempo como un tiempo de cambio en el interior de mi misma, mi cuerpo era el sur, el tiempo del sol cayendo me daba a pensar en todo ese viaje entre Argentina y París

cuando volví, dejé el film y tiempo más tarde (casi dos años) visualizando las imágenes, entendí el contenido político de lo que había filmado, el texto de Adam Smith me apareció, desde su titulo, La riqueza de las naciones, despliegue histórico de la construcción norte sur, el capítulo de las colonias fue una evidencia pues corresponde a la situación histórica que hoy se reactualiza, las cataratas significaban lo exótico de un paraíso primero a conquistar, pero también lo escondido, esa triple frontera de contrabando, entre Brasil, Argentina y Paraguay, cuerpo de la tierra divido por las fronteras que trazan los estados

los dos films, uno al lado del otro, hacen emergen otra pregunta, el capitulo 8 las colonias, del libro 4 de Las Riquezas de las Naciones, es un genérico de film pero va a la inversa, sube, dirigido al norte, texto que da a leer la justificación de acciones que destruyen a la impenetrable de la selva, y las cataratas salvajes van bajando, envueltas en el ruido y canto, coro de voces de sirenas de amazonas, interpelan al texto del

En un breve esbozo biográfico señalás que tu obra se inscribe en un work in progress, y usas un concepto muy evocativo para denominar este trabajo que va sucediendo sin establecer nunca un fin. Lo denominás traducción afectiva, vinculado a la comprensión del artista como intérprete traductor. Me interesa ese concepto. Pienso, por ejemplo, en el de arquitectura emocional, que propuso Mathias Goeritz. Él colocaba a la arquitectura en el lugar de una experiencia transformadora. En lugar de trabajar con planos trabajaba como un escultor, dando una forma particular a cada muro. Pienso que puede establecerse cierto paralelo, aunque la materia escultórica y la palabra activan los afectos de formas muy diferentes. Me dirás...

lo que dices me resuena totalmente, mi producción tanto en la escritura como en lo visual se acerca más a lo concreto, que, a la metáfora, es construcción de un lenguaje en movimiento, alfabeto nuevo, herramienta para deconstruir el muro de lo real,

cuando hablo del artista como un intérprete traductor, yo diría que este, traduce lo intraducible, ese punto sin retorno, punto de resistencia a lo real,

si hablo de la traducción afectiva, es porque ya traducir significa integrar algo de sí mismo en ese punto de vista desde el que se traduce, siendo el interprete de la singularidad de lo intraducible del sí mismo, es una idea que parte de mi interrelación con las lenguas, la materna y la francesa

mi materia para producir es la misma materialidad de mi cuerpo, en cierto modo esto se acerca a lo que avanzas cuando hablas de materia escultórica, pues es particular y única, territorio, tangible e intangible, espacio de abertura despliegue, yo me considero una escultora de lenguajes visuales y sonoros

una traducción es afectiva cuando va más cerca y más lejos, cuando cambia la escala y produce la propia, que es la única medida, la de si mismo,

ir tanteando mas allá del pensamiento del sentimiento del saber, es ir mas allá, y mas aquí, habitada por tantas lenguas antes y después de nacer, atravesada por una historia personal y múltiple, ser un prisma de facetas tantas, trompo que gira gira gira 
Durante esta conversación que hemos mantenido durante más de un mes, fui recibiendo tus respuestas y enviando nuevas preguntas. Me contuve ante el impulso natural que tengo como escritora en castellano y como editora, de corregir o editar tus respuestas. Comenzás todas las oraciones en minúscula, faltan comas, acentos, puntos. Existen desacuerdos gramaticales. Se percibe con toda claridad que esos descalces tienen un sentido poético. Hoy vamos a conversar sobre si haré o no una edición de los textos. Imagino que no. Conversemos, entonces, como final de esta entrevista, sobre el significado que otorgas a esos continuos deslizamientos entre palabras escritas.

con respecto a la corrección de ciertos errores (faltas de acentos, comas) generalmente, estoy de acuerdo, pero cuando se refiere a la construcción de la frase misma, soy un tanto reticente, pues esto que podría leerse como un error o una confusión, es, en realidad, el reflejo voluntario de una manera de nombrar un lugar, mi lenguaje sacar las letras mayúsculas del comienzo de cada fragmento, es un modo de señalar que lo que escribo es parte de un infinito, uno mas uno mas uno etc., nada tiene la jerarquía para ser primero, pues tanto mis textos como mis trabajos en el orden de la plástica, yo los considero fragmentos, y los fragmentos son todos pedazos de algo, no tienen ni principio ni fin, son parte del despliegue de lo mismo

dejo espacios y utilizo las comas, para significar con estos espacios, el vacío, que puede sentirse como una respiración, una pausa,

compongo desde un punto de vista espacial, como si estuviera esculpiendo, tanto mis textos como mis piezas de carácter visual, pueden leerse como partituras de música, o esculturas, a través de las cuales, traduzco e interpreto este gran rompecabezas en el que estoy inmersa desde antes de nacer, y si escribo en primera persona es porque voy afirmando, que doy testimonio.

\section{RESÚMENES}

Esta entrevista con la artista Julieta Hanono se realizó durante de 2019 en ocasión de su exposición Traducir la impenetrable, en el Museo de la Cárcova, en Buenos Aires. Julieta nació en Rosario, Argentina, y vive París. Durante su adolescencia estuvo detenida-desaparecida por la dictadura militar argentina. Estudió arte y filosofía en Argentina y luego en Francia. Su film El pozo remite a su experiencia en prisión. Durante los últimos años su trabajo se ha centrado en el tema de la traducción.

Cette entrevue avec l'artiste Julieta Hanono a été réalisée en 2019 à l'occasion de son exposition Traduire l'impenétráble, au musée de Cárcova, Buenos Aires. Julieta est née à Rosario, en Argentine, et vit à Paris. Pendant son adolescence, elle a été arrêtée par la dictature militaire argentine et disparue. Elle a étudié l'art et la philosophie en Argentine puis en France. Son film El pozo (Le Trou) fait référence à son expérience en prison. Au cours des dernières années, son travail s'est concentré sur le sujet de la traduction. 
This interview with artist Julieta Hanono was conducted in 2019 on the occasion of her exhibition Traducir la impenetrable (Translate the Impenetrable) at the Museo de la Cárcova in Buenos Aires. Julieta was born in Rosario, Argentina, and lives in Paris. As an adolescent, she was arresteddisappeared by Argentine military forces during the dictatorship. She studied art and philosophy first in Argentina and then in France. Her film El pozo (The Ditch) addresses her experience in prison. Her recent work has focused on the problem of translation.

\section{ÍNDICE}

Mots-clés: Julieta Hanono; Argentine; El pozo; traduction.

Palabras claves: Julieta Hanono; Argentina; El pozo; traducción.

Keywords: Julieta Hanono; Argentina; El pozo; ; translation.

\section{AUTOR}

\section{ANDREA GIUNTA}

Andrea Giunta es Doctora y Profesora de arte latinoamericano y moderno / contemporáneo en la facultad de Filosofía y Letras, Universidad de Buenos Aires. Investigadora principal de CONICET. Curadora de la Bienal 12, Porto Alegre, Brasil, 2020. 